\title{
Study on the Relationship between Campus Culture Construction and Foreign Language Discipline Construction
}

\author{
Lian-song $\mathrm{Wu}^{1}$, Hong-lian Liu ${ }^{2}$ \\ ${ }^{1}$ School of Foreign Studies, Yangtze University, Jingzhou, Hubei, China (wls@yangtzeu.edu.cn) \\ ${ }^{2}$ Jingzhou Experimental Middle School, Jingzhou, Hubei, China (lotuswilliam@vip.qq.com)
}

\begin{abstract}
As the intersection of construction and development of institutions of higher education, discipline construction is a long-term and arduous task. College campus culture is not only the blood and soul of university, is also the prominent characteristic and symbol among each other's. However, cultural construction and discipline development are closely related. Taking the school of foreign languages, Yangtze University as an example, this paper discussed the relationship between campus culture and foreign language discipline construction in levels of material culture, system culture, behavior culture and spiritual culture, so as to promote the healthy and continuous development of foreign language discipline construction.
\end{abstract}

Index Terms - Campus Culture; Foreign Language; Discipline Construction

\section{Introduction}

In recent years, with the continuous advancement of university's construction adjustment and the development of modern higher education, the competition between universities has become much fiercer. However, it is universally acknowledged that university's competence mainly depends on the effects of discipline construction. Discipline construction is a systematic project consisting of discipline orientation, staff, scientific research, personnel training, discipline base, discipline management, etc. It is the leading tap of university's construction and development as well as a longstanding and arduous task for the university. Discipline construction situation can radically represent a university's running level, running ability, running features, academic status, and core competence.

Campus culture, as a distinctive, unique subculture under the whole society's cultural background, is also an important part of social culture. Campus culture not only includes values and concepts that interlink social culture, but also sustain its own unique social culture values and status. It is because of this that campus culture, namely a university's running feature, scientific spirits, university concepts that makes a university's soul and blood, makes a university different from each other. In the practical running activities, these are the important connotation of discipline construction, and at the same time be represented through discipline construction.

Compared with other disciplines, foreign language discipline has always been nurtured by foreign culture, and is apt to be influenced by foreign cultures. Therefore, foreign language teachers are required to possess lofty ideological cultivation, sound and harmonious personality, favorable psychological educational cultivation. Furthermore, teachers are expected to meet higher standard in professional knowledge, humanity cultivation, lifelong studying habits and educational scientific research. While presenting professional features and impart professional techniques and skills, how to further exploit campus culture's positive education and piloting function plays a important role in foreign language development. This paper intends to promote foreign language discipline' $\mathrm{s}$ sound and sustainable development by combining the first class achievement of the $7^{\text {th }}$ Ministry of Education's prominent campus culture ---Sunshine Culture from the school of foreign languages, Yangtze University and exploring the relationship between campus culture construction and foreign language development.

\section{The Connotation and Function of Sunshine Culture}

\section{A. The Connotation of Sunshine Culture.}

Sunshine culture advocates a sunshine life that enjoys mentality happiness. It also strives to cultivate a favorable sunshine environment and to build a "three whole system" (whole staff, whole position, and whole process). Sunshine culture is an education comprised of live, intelligence, and heart. It focuses on cultivating individual competence which can help the all-round development of foreign language intellects.

Sunshine culture is the college culture of the school of foreign languages, Yangtze University. It is a prominent campus culture, and is also a presentation of foreign language academy's professors' and students' spiritual pursuits, value orientation, conduct regulation and living environment. Sunshine culture originates from the campus, and radiates to the families and society, which is also a educational culture. It constructs a sunshine environment favorable for development from the whole and forms a sunshine educational atmosphere.

\section{B. The Functions of Sunshine Culture}

1) Positive leading function.

Sunshine culture takes cultivating healthy and kind-hearted life, vivid and intelligent brain, rich and lofty soul as its development goal. And uses "bright and warm" sunshine spirits to pilot and encourage the large-scale students, which plays a role of encouragement and leading.

2) Solidarity function.

Sunshine culture takes inheriting "sunshine train" youth 
volunteer spirits as its foundation, absorbs the nutrients of Chinese spirits and socialist core values, excavates characteristics buried in "sunshine", refines sunshine spirits, which vividly describes the goal of education, and plays a role of inciting and solidarity.

3) Cultural education function.

Sunshine culture promotes education through penetrating into different aspects like education, management, service and different procedures like classroom teaching, campus cultural activities and social practice. With its energetic and influencing genes, sunshine culture can inspire different energy, build a "3 whole system" (whole staff, whole position, whole process), which helps to form an educational joint force, amplify educational effects and achieve the goal of cultural education function.

\section{The Relationship between Sunshine Culture and Foreign Language Discipline Construction}

Culture construction has close internal correlations with discipline construction. As for Foreign Language Department of Yangtze University, on the one hand, foreign language discipline contains Sunshine Culture. On the other hand, the construction and further development of Sunshine Culture are surely to promote the development of foreign language discipline construction. Sunshine Culture and foreign language discipline are inextricably linked in four layers-environment culture, institution culture, behavior culture and spirit culture.

\section{A. The Construction of Sunshine Environment Culture Servers as the Material Carrier of Foreign Discipline Construction}

As Dr. Tao Xingzhi said, even plant has sentiment. Campus environment culture is physical form of campus culture and material carrier of campus spirit culture. Campus environment culture is a visible part of campus culture. It refers to cultural mentality which is visible, tangible and embodied.

Good campus culture is reflected by putting emphasizes on innovation in management, promotion of qualification, social reputation and material phenomena such as campus environment, atmosphere and cultural facilities. Positive campus culture contributes greatly to education. A campus which is agreeable to you and makes you perfectly happy to be together with it is a great power itself. Saturated in such atmosphere for a long run, teachers and students regulate their behaviors, model their sentiment and get a promotion of their quality. Therefore, a positive reinforce is strengthened between party and government, governors and public, and teachers and students.

The construction of Sunshine Environment Culture can be divided into two major parts. One is the environment construction of sunshine campus, sunshine class, sunshine dorm and sunshine classroom. Campus feature activities such as sunshine competitions, sunshine speeches, sunshine community activities, sunshine assessment and sunshine festival, class construction and sunshine dorm competition, all these create a good studying and living atmosphere, and advocate a class of love, perseverance, confidence, joy, interest and passion. The other is the construction of sunshine academic environment. A good academic environment is essential for elevation of the level of subject, therefore, the construction of academic environment should be the core of construction of campus culture and an important facet of discipline construction. Charitable academic environment benefits the promotion of academic freedom, the nurture of innovation and the elevation of independent innovation capacity; the policy environment that encourages innovation contributes to the construction of academic standard, the cultivation of the creative talents and the promotion of high-qualified brains; harmonious social environment is good for the formation of academic team, the elevation of overall quality of academic team and the further development of science.

\section{B. The Construction of Sunshine Institution Culture is the Base Safeguard of Foreign Language Discipline Construction}

Institution culture is a kind of custom culture which includes teaching rules, administration rules and students' standard behavior, as well as habits, proprieties, school spirit, studying spirit and class spirit.

Campus institution culture influences school members as an outside binding force. For it is not simply meant to limit or restrict, but also to form their consistent concept and a code of behavior through approving and obeying these rules and regulations. Institution itself is a part of education-while obeying these rules and regulations, people improve their perception and fall into good habits. Serving as the basic guarantee of campus built and management, campus institution culture plays roles of leading, limiting and regulating.

Sunshine institution culture absorbs and adapts construction experiences of famous universities in China, and assembles all these refer to fields of education and teaching, teaching research, training of talented people, students work and so on to make it a conducting guidance for all the stuff and students. This will surely become a powerful security system for foreign language discipline construction.

\section{Sunshine Behavior Culture is the External Manifestation of Language Disciplines \\ Behavior culture is that teachers and students reflect and} practice the campus culture by practical action in the teaching management and learning exercise. Behavior culture emphasize the status of "man" in the campus culture, teachers and students are the main part of behavior culture. Behavior culture is the "living culture "in the campus, is a barometer of the campus culture as well as the total refraction of all cultures. It is the mental status, behavior, size and taste exhibited by the teachers and students in their work and life and of the various behaviors in, and it is also a dynamic reflection of the school spirit, values and educational philosophy. Teaching, study and style are the concentrated expression of school teachers, students and management workers' behavior. 
Both behavior culture influence and restrict the construction of school discipline to some extent, and it is also a concrete manifestation of the school discipline construction level and its effects.

The construction of Sunshine Behavior Culture mainly regulates the behavior of teachers and students in nine aspects: quality, attitude, habits, behavior, learning, practice, teaching, management and service. It takes the "people-oriented" as its concept; respect the interests of faculties' development as well as the values and aspirations. It also tries to promote the joint achievement of the department and the faculties' value. To put forward specific requirements to teachers from the education standards, teaching standards, communication etiquette norms, learning activity norms and other aspects. Also, to require teachers by a code of conduct;

Guide teachers to respect and understand students by teaching them to learn to devote, learn to cooperate, learn to understand, learn to be patient, learn to tolerant, and learn to give up. It Guides teachers, in a fair manner and broad-minded eyes, discovers and appreciates the students to reach the goal of making education to be more practical. And eventually formulate a loose, harmony, equality and respectful cultural circumstance, thus to enhance the sense of ownership of the faculties, and promote the literacy and taste of teachers and students.

\section{The Construction of the Sunshine Spiritual Culture is the Heart and Soul of Language Disciplines.}

Spiritual culture is the core content of the campus culture. Good campus spiritual culture conducive to the formation of a strong education and learning atmosphere, it can also have an impact on the place where education can hardly get to reach directly or cannot be fully effective, and to become guide of education and its useful supplement. Spiritual culture are the heart of the campus culture, including the school's mission, vision, spirit, values and ethics as well as style, it is the sum of the school ideology.

The basic task of school construction is building talent, achievements and get up the level. The spirit of majority faculties, the attitude and even the moral conscience choice, decided the success of disciplines. To solve the problem, it is necessary to go deeply into the problem and then preserve, insist to push ahead. Then it will be possible to bring the level of discipline construction.

Based on this, the sun cultural of the Foreign Language Department in the Yangtze University take "brightness and warmth" as the sun spirit, and constantly enrich the philosophy of "love, faith, perseverance and happy". It also promotes a positive energy that can be transferred, prompt staffs to be more active, more involved in teaching and research work. On this basis, the sun culture will continue to fully absorb the culture of the modern universities' spirit, and constantly enrich the spiritual and cultural connotations, enhance the solidarity and cohesion, thus to make it becomes the common values and vision that pursued by the staffs and students in the Foreign Language Department, and also to become the internal support system and curriculum development souls in the college campus culture.

\section{Conclusion}

In short, the campus culture is the value orientation of a school that gradually formed in the long process of development, which is a comprehensive reflection of spiritual pursuit, group mentality and behavior norms. The process of first class academic development is also a process that an excellent university campus culture and spirit gradually aggregated, optimized and promoted.

As a good representative of the campus culture, the Sunshine Culture and Foreign Language development are closely related; both of them supplement each other and interact as both cause and effect. Only by putting the Sunshine culture into every aspect of the foreign discipline construction, truly forming and cohering campus culture with distinctive characteristics and unique advantages can we further promote the development of foreign language subjects, and train more qualified and innovative foreign language entrepreneurial talents to meet the development needs of the times.

\section{References}

[1] Zhang Dejiang, Combination of Cultural Construction and the Subject, Enhancement of Hard Power and Soft Power, Chinese higher Education, 2009 (5): 19-20.

[2] Zhao Zongfeng, On the Campus Culture Construction of the First Class Foreign Language University, Chinese higher education research, 2004 (6). 